\title{
The Optimization of Greenhouse Gas Reduction and Odor Emissions from Wastewater Treatment Plant
}

\author{
Ji Ye Yoo, Eun Ji Woo, and Chan Jin Park
}

\begin{abstract}
Wastewater treatment generates significant amount of greenhouse gases mainly methane and nitrous oxide. Therefore, reducing these emissions from the treatment process and the contribution of the wastewater treatment processes to global warming is a major concern. Also, odors can be generated and released from virtually all phases of wastewater collection, treatment, and disposal. Most odor-producing compounds found in domestic wastewater and in the removed solids result from anaerobic biological activity that consumes organic material, sulfur, and nitrogen found in the wastewater. In this study, estimation of greenhouse gas and reduction of greenhouse gas and odor emissions from wastewater treatment plants in urban areas were made.
\end{abstract}

Index Terms-Wastewater treatment plant, greenhouse gas, odors.

\section{INTRODUCTION}

These days, emission of greenhouse gases has been rapidly and tremendously increased. As a result, greenhouse effect was accelerated, and it caused climate change. Almost $5 \%$ of the total greenhouse gas emissions are known to occur in wastewater treatment plants [1].

Wastewater treatment generates significant amount of greenhouse gases mainly methane and nitrous oxide.

Centralized wastewater treatment methods can be classified as primary, secondary, and tertiary treatment. In primary treatment, physical barriers remove larger solids from the wastewater. Remaining particulates are then allowed to settle. Secondary treatment consists of a combination of biological processes that promote biodegradation by micro-organisms. These may include aerobic stabilisation ponds, trickling filters, and activated sludge processes, as well as anaerobic reactors and lagoons. Tertiary treatment processes are used to further purify the wastewater of pathogens, contaminants, and remaining nutrients such as nitrogen and phosphorus compounds. This is achieved using one or a combination of processes that can include maturation/polishing ponds, biological processes, advanced filtration, carbon adsorption, ion exchange, and disinfection.

Wastewater can be a source of methane $\left(\mathrm{CH}_{4}\right)$ when

Manuscript received March 30, 2016; revised August 8, 2016

J. Y. Yoo is with the Department of Climate International Cooperation, Incheon National University, Republic of Korea (e-mail: yoojiye@inu.ac.kr).

E. J. Woo is with the Department of Environment and Energy Engineering, Incheon National University, Incheon, Republic of Korea (email:wej5366@inu.ac.kr).

C. J. Park is with the Department of Energy and Env. Engineering and the Department of Climate International Cooperation, Incheon National University, Republic of Korea (e-mail: cjpark@inu.ac.kr). treated or disposed anaerobically. It can also be a source of nitrous oxide $\left(\mathrm{N}_{2} \mathrm{O}\right)$ emissions. Carbon dioxide $\left(\mathrm{CO}_{2}\right)$ emissions from wastewater are not considered in the IPCC Guidelines because these are of biogenic origin and should not be included in national total emissions. Therefore, reducing these emissions from the treatment process and the contribution of the wastewater treatment processes to global warming is a major concern.

Also, odors can be generated and released from virtually all phases of wastewater collection, treatment, and disposal. Most odor-producing compounds found in domestic wastewater and in the removed solids result from anaerobic biological activity that consumes organic material, sulfur, and nitrogen found in the wastewater.

In this study, estimating greenhouse gas emissions from wastewater treatment plants in urban areas, and it attempted to reduce greenhouse gas emissions and odors.

\section{MECHANISM OF GREENHOUSE GASES GENERATED IN WASTEWATER TREATMENT PLANTS}

In Fig. 1 a wastewater treatment plant is schematically displayed. The different boxes show the treatment processes. The GHGs that can be released during the treatment processes are given in the circles. The numbers in the figure correspond with the numbers of the list of boundaries [2].

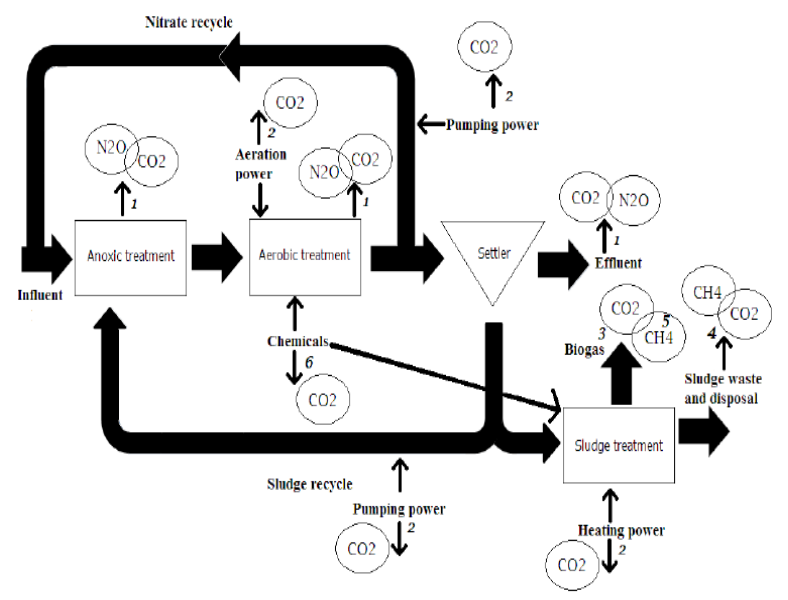

Fig. 1. Greenhouse gas emissions of a wastewater treatment plant that are taken into account [2]

\section{A. Methane $\left(\mathrm{CH}_{4}\right)$}

Wastewater as well as its sludge components can produce $\mathrm{CH}_{4}$ if it degrades anaerobically. The extent of $\mathrm{CH}_{4}$ production depends primarily on the quantity of degradable organic material in the wastewater, the temperature, and the type of treatment system. With increases in temperature, the rate of $\mathrm{CH}_{4}$ production increases. This is especially 
important in uncontrolled systems and in warm climates. Below $15^{\circ} \mathrm{C}$, significant $\mathrm{CH}_{4}$ production is unlikely because methanogens are not active and the lagoon will serve principally as a sedimentation tank. However, when the temperature rises above $15^{\circ} \mathrm{C}, \mathrm{CH}_{4}$ production is likely to resume. The principal factor in determining the $\mathrm{CH}_{4}$ generation potential of wastewater is the amount of degradable organic material in the wastewater. Common parameters used to measure the organic component of the wastewater are the Biochemical Oxygen Demand (BOD) and Chemical Oxygen Demand (COD). Under the same conditions, wastewater with higher COD, or BOD concentrations will generally yield more $\mathrm{CH}_{4}$ than wastewater with lower COD (or BOD) concentrations. [3]

\section{B. Nitrous Oxide $\left(\mathrm{N}_{2} \mathrm{O}\right)$}

Nitrous oxide $\left(\mathrm{N}_{2} \mathrm{O}\right)$ is associated with the degradation of nitrogen components in the wastewater, e.g., urea, nitrate and protein. Domestic wastewater includes human sewage mixed with other household wastewater, which can include effluent from shower drains, sink drains, washing machines, etc. Centralized wastewater treatment systems may include a variety of processes, ranging from lagooning to advanced tertiary treatment technology for removing nitrogen compounds. After being processed, treated effluent is typically discharged to a receiving water environment (e.g., river, lake, estuary, etc.). Direct emissions of $\mathrm{N}_{2} \mathrm{O}$ may be generated during both nitrification and denitrification of the nitrogen present. Both processes can occur in the plant and in the water body that is receiving the effluent. Nitrification is an aerobic process converting ammonia and other nitrogen compounds into nitrate $\left(\mathrm{NO}_{3}{ }^{-}\right)$, while denitrification occurs under anoxic conditions (without free oxygen), and involves the biological conversion of nitrate into dinitrogen gas $\left(\mathrm{N}_{2}\right)$. Nitrous oxide can be an intermediate product of both processes, but is more often associated with denitrification [3], [4].

\section{MECHANISM OF OdORS GENERATED IN WASTEWATER TREATMENT PLANTS}

Any place or process in which wastewater is collected, conveyed or treated has the potential to generate and release nuisance odors to the surrounding area. However, most odor problems occur in the collection system, in primary treatment facilities and in solids handling facilities. In most instances, the odors associated with collection systems and primary treatment facilities are generated as a result of an anaerobic or "septic" condition. This condition occurs when oxygen transfer to the wastewater is limited such as in a force main. [5]

In the anaerobic state, the microbes present in the wastewater have no dissolved oxygen available for respiration. This allows microbes known as "sulfatereducing bacteria" to thrive. These bacteria utilize the sulfate ion $\left(\mathrm{SO}_{4}^{-}\right)$that is naturally abundant in most waters as an oxygen source for respiration.

The byproduct of this activity is hydrogen sulfide $\left(\mathrm{H}_{2} \mathrm{~S}\right)$. This byproduct has a low solubility in the wastewater and a strong, offensive, rotten-egg odor. In addition to its odor, $\mathrm{H}_{2} \mathrm{~S}$ can cause severe corrosion problems as well. Due to its low solubility in the wastewater, it is released to the atmosphere in areas such as wet wells, headworks, grit chambers and primary clarifiers. There are typically other "organic" odorous compounds, such as mercaptans and amines, present in these areas, but $\mathrm{H}_{2} \mathrm{~S}$ is the most prevalent compound.

Solids handling facilities are another significant odor problem area. In biosolids dewatering and treatment processes, the biosolids commonly undergo extreme turbulence, $\mathrm{pH}$ adjustment and/or thermal treatment. Depending on the nature of the biosolids stream and the treatment used, the odor compounds released can consist of any combination of the following compounds in a wide range of concentrations: ammonia, amines, hydrogen sulfide, organic sulfides and mercaptans. Additionally, anaerobic digestion of sludge creates the anaerobic conditions in which sulfate-reducing bacteria thrive, causing the formation of hydrogen sulfide that is vented with the digester "biogas" formed from the digestion of sludge.

\section{Odor Control Treatment Method}

\section{A. Carbon Adsorption}

In a carbon adsorption system, the air stream is passed over a bed of adsorbent (carbon) and the odor-causing compounds are attracted to and adhere to the surface of the adsorbent. This is the simplest of the three wastewater odor control technologies. There is no on-going chemical supply to the system, and there are no biological processes to be upset. Adsorption is applicable to a wide range of compounds. Hydrogen sulfide and related sulfur-based compounds are removed effectively by carbon adsorption systems, but ammonia and other nitrogen-based compounds are not effectively treated. Various carbon type systems including activated and impregnated can be used independently or in combinations to remove many different contaminants [5].

\section{B. Biofiltration}

Biofiltration technology can be used to treat a variety of biodegradable, water-soluble contaminants. In a biofilter, the odor contaminants are solubilized from the vapor phase into an aqueous phase on the surface of an organic medium such as compost, mulch or peat. The compounds are then degraded by the bacteriological population on this media. Biofilters are very effective at removing sulfur-based odor compounds such as hydrogen sulfide, organic sulfides and mercaptans. Biofilters generally are not effective at removing nitrogen-based compounds such as ammonia and amines. Two major challenges in biofiltration systems are stability of the media and control of the biofiltration process. The media used in biofilters can be prone to breakdown. When this occurs, the bed settles and compacts, increasing the headloss through the filter. This causes a decrease in airflow and fugitive odor emissions typically result from the air source. Control of the biofiltration process also is an important concern. The biological population within the filter is subject to upsets, as are any organisms. If the media are exposed to wide swings in environmental conditions, upset of the bacteria population may result and breakthrough odors will occur [5]. 
The bacteria grow on inert supports, allowing intimate contact between the odorous gases and the bacteria. The process is selfsustaining. Bio-filters can be constructed using various materials such as compost, straw, wood chips, peat, soil, and other inexpensive biologically active materials [6].

\section{Wet Air Scrubbing}

Wet air scrubbing is the most flexible and reliable technology for vapor-phase wastewater odor control. This technology can be used to treat virtually any water-soluble contaminant. In addition to hydrogen sulfide and "organic" odors, wet scrubbing is very effective for ammonia removal. In a wet air scrubber the odor contaminants are solubilized from the vapor phase into an aqueous chemical solution. The removal mechanism is purely chemical and is not subject to upsets as are biological processes. The chemical balance in the system is automatically and continuously maintained, even under changing loading conditions, minimizing the chance for odor break-through. The application of a multi-stage scrubber allows the utilization of a different chemical solution in each of the stages to efficiently use chemicals and target a wide range of contaminants for treatment.

One major advantage of wet scrubbing systems is the reliability and flexibility provided by the use of chemicals and chemical reactions. A major challenge in the design and operation of wet air scrubbers is the minimization of chemical use and cost while maintaining complete, flexible and reliable treatment. One design used to reduce chemical use is the multi-stage scrubbing system. As mentioned above, in raw wastewater odor control applications the most prevalent contaminant is hydrogen sulfide, but other organic odorous compounds typically are present as well. Hydrogen sulfide can be solubilized with a solution of sodium hydroxide. However, the other odor-causing compounds are best treated by sodium hypochlorite. In a single-stage scrubber system, sodium hydroxide and sodium hypochlorite are used in a recirculating chemical solution. Since sodium hypochlorite is a strong oxidizer, it readily reacts with the sulfide that is solubilized by the sodium hydroxide. Therefore, in a single-stage system sodium hypochlorite must be added in sufficient quantities to oxidize the hydrogen sulfide and maintain a residual to treat the other odor compounds. In a multi-stage system, sodium hydroxide is used alone in the first stage to solubilize hydrogen sulfide. Sodium hypochlorite is added to the last stage only. By eliminating the sodium hypochlorite from the sulfide removal process, the consumption rate for this chemical is greatly reduced [5].

\section{CURRENT State OF AFFAIRS In WASTEWATER TREATMENT PLANTS}

This Table I shown wastewater treatment amount of 2007 to 2013 which one of city in Republic of Korea.

Table II shown wastewater treatment method by selected a typical wastewater treatment plant six locations in the area.

The civil appeals of wastewater odors has increased year by year. In particular, there has increased rapidly since 2011 . (Fig. 2)

\begin{tabular}{cc} 
TABLE I: STATE OF WASTEWATER TREATMENT [7] \\
\hline Year & $\begin{array}{c}\text { Wastewater amount } \\
\text { (unit : } 1000 \text { ton) }\end{array}$ \\
\hline 2007 & 6535 \\
2008 & 6349 \\
2009 & 6716 \\
2010 & 6937 \\
2011 & 6266 \\
2012 & 6973 \\
2013 & 7557 \\
2014 & 7065
\end{tabular}

TABLE II: WASTEWATER TREATMENT METHOD [7]

\begin{tabular}{ll}
\hline Case & Wastewater treatment method \\
\hline A & MLE+MDF, 4-stage BNR+MDF \\
B & MLE+coagulation+precipitation \\
C & Bio-SAC \\
D & KSMBR+URC \\
E & A $^{2}$, DF-MBR \\
F & Oxidation ditch method \\
\hline
\end{tabular}

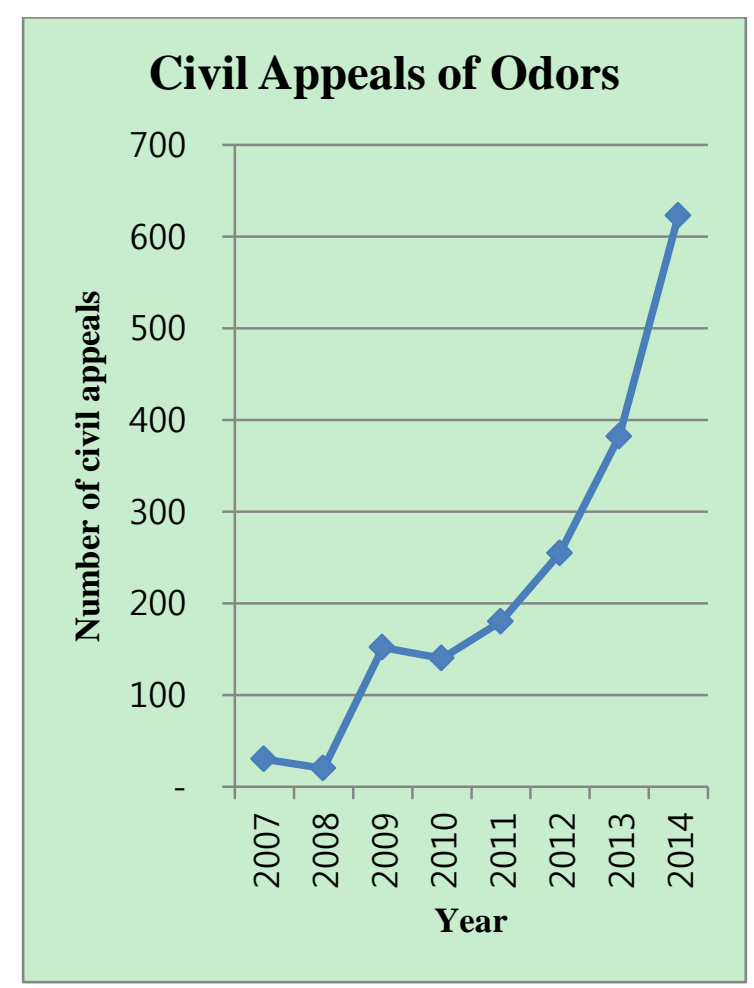

Fig. 2. Civil appeals of wastewater odors [8].

Table III shown odor control treatment method by selected a typical wastewater treatment plant six locations in the area.

TABLE III: OdOR CONTROL TREATMENT METHOD [7]

\begin{tabular}{|c|c|}
\hline Case & Odor control treatment method \\
\hline A & $\begin{array}{c}\text { Bio-Filter, Wet Scrubber, } \\
\text { Active carbon absorption process, } \\
\text { Catalytic combustion method, } \\
\text { Whirlpool mixing type }\end{array}$ \\
\hline B & Bio-Filter \\
\hline $\mathrm{C}$ & Bio-Filter \\
\hline $\mathrm{D}$ & Bio-Filter \\
\hline $\mathrm{E}$ & Bio-Filter \\
\hline $\mathrm{F}$ & Bio-Filter \\
\hline
\end{tabular}


Table IV shown the odor emissions of outlet and site boundary in 2013 and 2014. By using the odor units.

\begin{tabular}{lcccc}
\multicolumn{4}{c}{ TABLE IV: ODOR EMISSIONS [7] } \\
\hline \multirow{2}{*}{ Case } & \multicolumn{2}{c}{2013} & \multicolumn{2}{c}{2014} \\
\cline { 2 - 5 } & Outlet & $\begin{array}{l}\text { Site } \\
\text { boundary }\end{array}$ & Outlet & $\begin{array}{l}\text { Site } \\
\text { boundary }\end{array}$ \\
\hline A & 206 & 5.5 & 201.4 & 4 \\
B & 247 & 7.6 & 294.8 & 6.5 \\
C & 134 & 8.5 & 233.7 & 5.8 \\
D & 49 & 8.8 & 276.9 & 4.1 \\
E & 323 & 7.3 & 410.5 & 5.5 \\
F & 171 & 8.5 & 226.6 & 4.9 \\
\hline
\end{tabular}

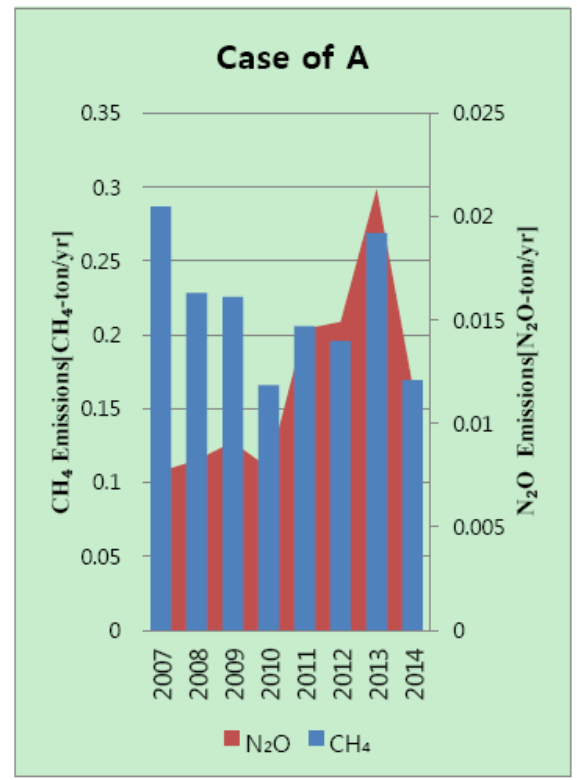

Fig. 3. $\mathrm{CH}_{4}, \mathrm{~N}_{2} \mathrm{O}$ Emission of A WWTP.

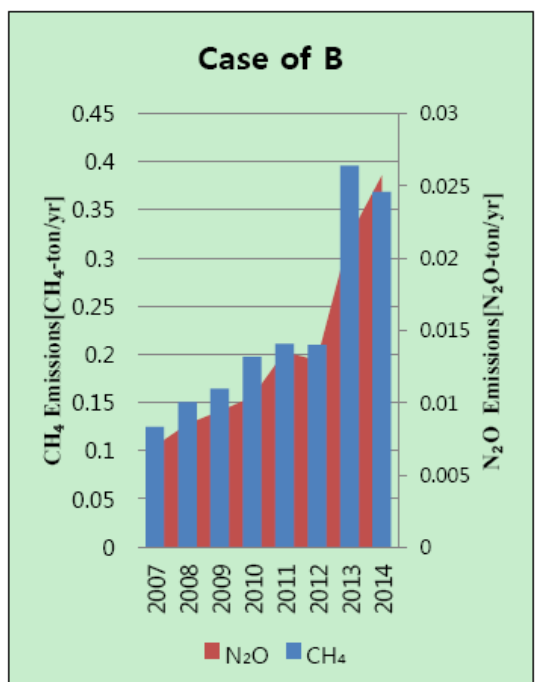

Fig. 4. $\mathrm{CH}_{4}, \mathrm{~N}_{2} \mathrm{O}$ Emission of B WWTP.

Fig. $3 \sim$ Fig. 8 shown $\mathrm{CH}_{4}$ and $\mathrm{N}_{2} \mathrm{O}$ Emission of each WWTP by selected a typical wastewater treatment plant six locations in the area. Wastewater and Sewage used following formula to calculate the greenhouse gas emissions [9].

$$
\begin{aligned}
\mathrm{CH}_{4} \text { Emissions }= & {\left[\left(B O D_{\text {in }}-B O D_{\text {out }}\right) \times 10^{-3} \times Q_{\text {in }} \times\right.} \\
& E F-R] \times 10^{-3}
\end{aligned}
$$

$\mathrm{CH}_{4}$ Emissions: $\mathrm{CH}_{4}$ emissions from sewage and wastewater treatment $\left(\mathrm{CH}_{4}\right.$-ton/yr)

$B O D_{\text {in }}: \mathrm{BOD}_{5}$ concentration of inflow sewage and wastewater (mg-BOD/L)

$B O D_{\text {out }}: \mathrm{BOD}_{5}$ concentration of sewage and wastewater (mg-BOD/L)

$Q_{\text {in }}$ : Sewage and wastewater $\operatorname{Inflow}\left(\mathrm{m}^{3} / \mathrm{yr}\right)$

EF: Emission factor $\left(\mathrm{kg}-\mathrm{CH}_{4} / \mathrm{kg}-\mathrm{BOD}\right)$

R: Recovery of Methane amount $\left(\mathrm{kg}-\mathrm{CH}_{4} / \mathrm{yr}\right)$

$\mathrm{N}_{2} \mathrm{O}$ Emissions $=\left[\left(T N_{\text {in }}-T N_{\text {out }}\right) \times 10^{-3} \times Q_{\text {in }} \times E F \times\right.$ $\left.\frac{44}{28}\right] \times 10^{-3}$

$\mathrm{N}_{2} \mathrm{O}$ Emissions: $\mathrm{N}_{2} \mathrm{O}$ emissions from sewage and wastewater treatment $\left(\mathrm{N}_{2} \mathrm{O}\right.$-ton/yr)

$T N_{\text {in }}$ : Total nitrogen concentration of inflow sewage and wastewater (mg-N/L)

$T N_{\text {out }}$ : Total nitrogen concentration of sewage and wastewater $(\mathrm{mg}-\mathrm{N} / \mathrm{L})$

$Q_{\text {in }}$ : Sewage and wastewater Inflow $\left(\mathrm{m}^{3} / \mathrm{yr}\right)$

EF: Emission factor $\left(\mathrm{kg}-\mathrm{N}_{2} \mathrm{O}-\mathrm{N} / \mathrm{kg}-\mathrm{N}\right)$

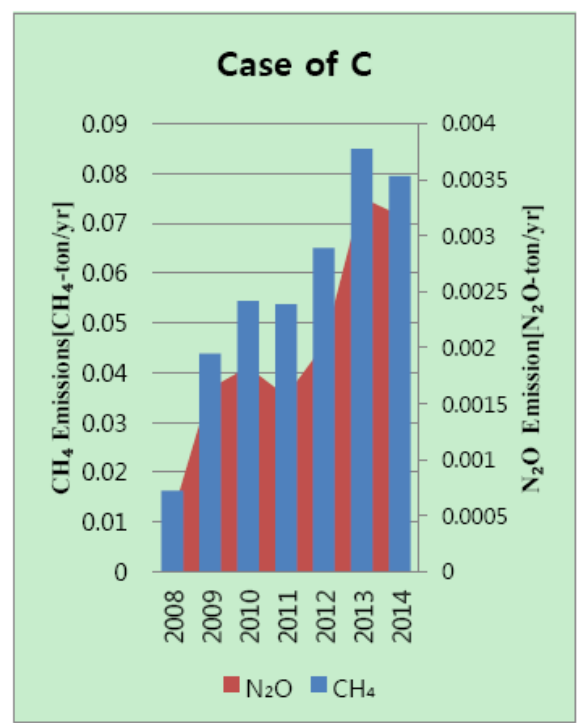

Fig 5. $\mathrm{CH}_{4}, \mathrm{~N}_{2} \mathrm{O}$ Emission of C WWTP.

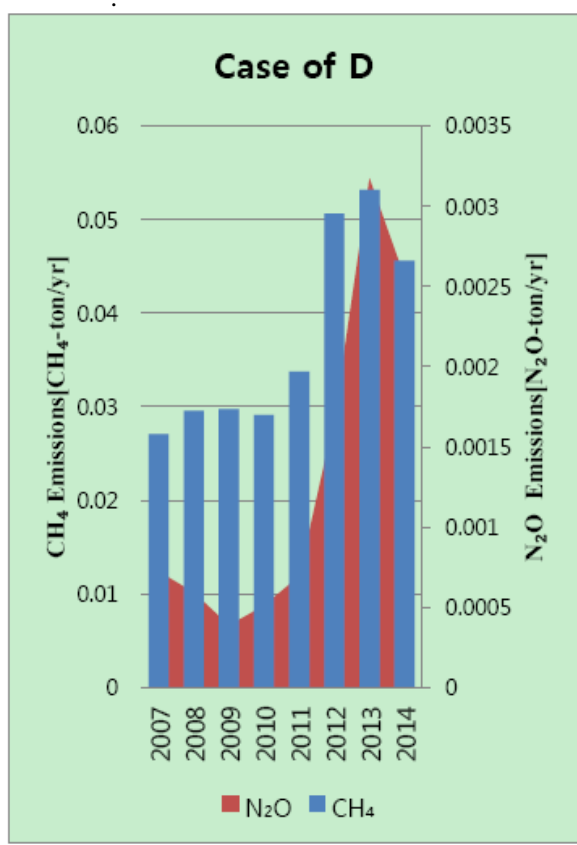

Fig. 6. $\mathrm{CH}_{4}, \mathrm{~N}_{2} \mathrm{O}$ Emission of D WWTP. 


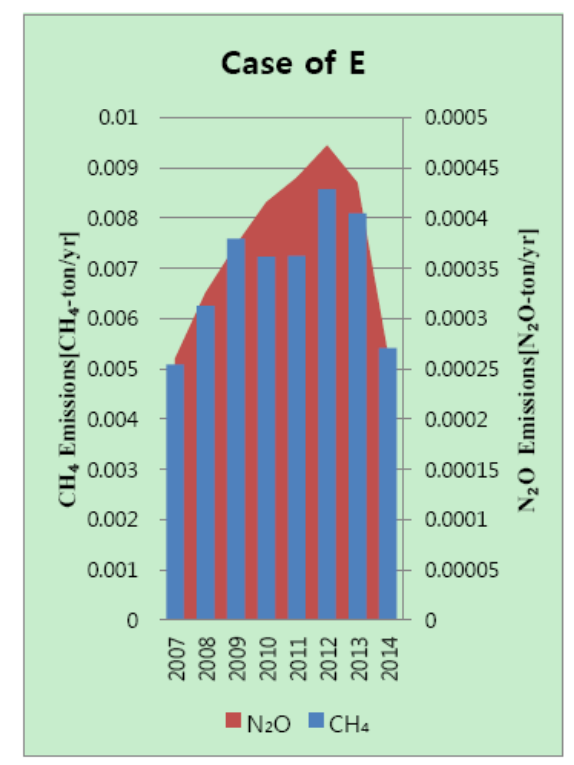

Fig. 7. $\mathrm{CH}_{4}, \mathrm{~N}_{2} \mathrm{O}$ Emission of E WWTP.

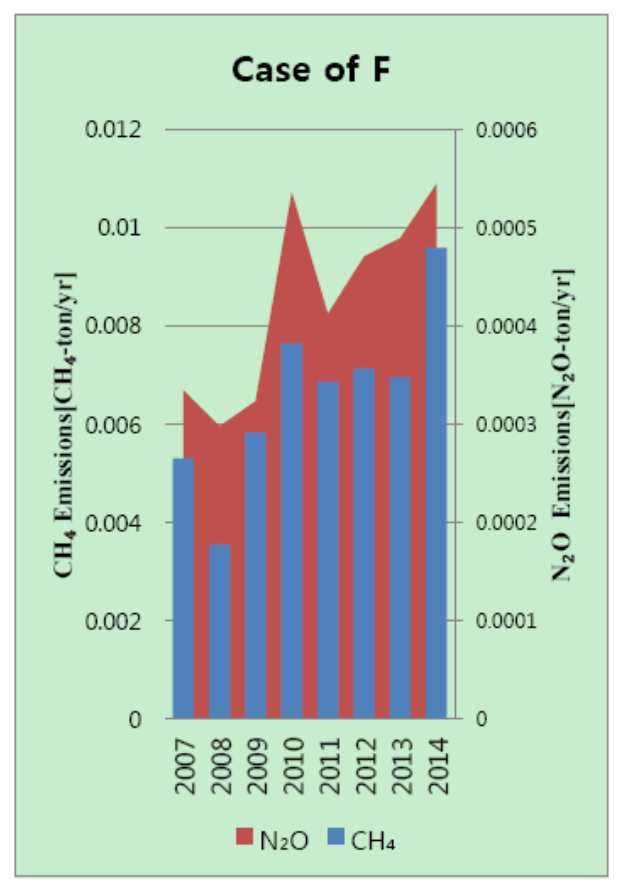

Fig. 8. $\mathrm{CH}_{4}, \mathrm{~N}_{2} \mathrm{O}$ Emission of F WWTP.

\section{CONCLUSION}

In 2013, wastewater treatment amount was increased, along with greenhouse gas emissions. The most often discharge the amount of greenhouse gas emissions was B wastewater treatment plant.

And the most often discharge the amount of odors emissions was E wastewater treatment plant. In spite of high concentration of outlet, site boundary concentration was very low. Odor management of waste water treatment plant is getting better.

For the effective management of odor, it has to be perform to identify the concentration of sulfur compounds emitted from sewage, night-soil, livestock treatment facility. And then it is required to establish the comprehensive odor management plan on operation, facility and process, odor control facility such as to minimize odor emission rate by means of operation of odor source, improvement of facility and process, and to install and operate optimum odor control facility after re-identifying concentration level of sulfur compounds, and also required to manage it systematically.

In order to reduce the greenhouse gas emissions from wastewater treatment plants, introduced of the highefficiency blower by replacing conventional blower. And it was done to improve the structure of the ventilating equipment. As a result, wastewater treatment plant reduces power consumption, and greenhouse gas emissions were reduced.

\section{ACKNOWLEDGMENT}

This work is financially supported by Korea Ministry of Environment (MOE) as "Knowledge-based environmental service Human resource development Project".

\section{REFERENCES}

[1] S. Solomon, D. Qin, M. Manning, Z. Chen, et al., "IPCC climate change 2007: The physical science basis." Contribution of Working Group I to the Fourth Assessment Report of the Intergovernmental Panel on Climate Change, Cambridge University Press, Cambridge, United Kingdom and New York, NY, USA. 2007

[2] L. Snip, "Quantifying the greenhouse gas emissions of wastewater treatment plants," Ms.C. thesis, Wageningen Univ., Netherlands, 2009

[3] R. J. D. Michiel, S. Towprayoon, S. M. M. Vieira, W. Irving, C. Palmer, R. Pipatti, and C. Wang, 2006 IPCC Guidelines for National Greenhouse Gas, 2006.

[4] D. Gupta and S. K. Singh, "Greenhouse gas emissions from wastewater treatment plants: A case study of noida," Journal of Water Sustainability, vol. 2, issue 2, pp. 131-139, June 2012.

[5] T. Barnette et al., Wastewater Odor Control: An Evaluation of Technologies, 2000

[6] Central Pollution Control Board Ministry of Environment \& Forests Govt. of India, Guidelines On Odour Pollution \& Its Control, 2008

[7] Environmental Corporation of Incheon, "A white paper on Environmental Corporation of Incheon," 2015.

[8] Korea Ministry of Environment Office of Water and Wastewater life sewerage, Statistics of Sewerage 2014, 2015.

[9] The Korean Society of Climate Change Research, Greenhouse Gas Emissions and Statistics, pp. 266-367, 2014.

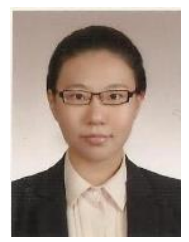

JiYe Yoo graduated from Incheon National University, and got master degrees in same university. Her major fields of research are the air pollution control, greenhouse gas and odor management. She is now enrolled in a doctoral course at the Department of Climate International Cooperation, Incheon National University, Republic of Korea.

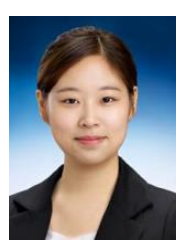

EunJi Woo was born in Republic of Korea on March 14, 1992. She attends in master's course of the Dept. of Environment and Energy Engineering in Graduate School of Incheon National University.

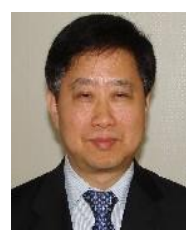

Chan Jin Park graduated from Korea University, and got Master and $\mathrm{PhD}$ degrees in same university. His major fields of research are the air pollution control, greenhouse gas technology and odor management technology. His another interest is green growth policy. $\mathrm{He}$ is now full-professor in Incheon National University at Urban and Environmental Engineering School. 